\title{
Reproduction Classical Characters In Girilayu Contemporary Batik Design
}

\author{
Desy Nurcahyanti' ${ }^{1}$, Agus Sachari ${ }^{2}$, and Achmad Haldani Destiarmand ${ }^{3}$ \\ ${ }^{1,2,3}$ Bandung Institute of Technology, Bandung, Indonesia \\ ${ }^{1}$ desynurcahyanti@students.itb.ac.id, 2aasachari@yahoo.com, \\ \& achmadhaldani@yahoo.com
}

\begin{abstract}
The composition of stilative ornaments form and the color of classical batik show a complexity of wise advice; which are able to direct human life from distructive to a more meaningful era. Contradictory problems arise against the efforts of batik artists to traditionally develop Girilayu batik through hand writing process, i.e. the existence of a cloth with classical batik motifs done by a printing process which indirectly obscures its values and philosophical meanings. This study aims to describe the correlation of contemporary batik designs in Girilayu with the character of classic batik from an aesthetic perspective. The method used in this research is hermeunitic approach to find out the essence of contemporary batik designs development in Girilayu. To strengthen the analysis, the researcher conducted interviews with Girilayu batik artists as the reproducers of classical character batik. Documentative data related to Girilayu style batik were collected and reduced to find interpretations which fit the existing problem. The effort done by batik artists to reproduce classical characters in contemporary batik designs in Girilayu is by restoring the distinctive character of batik by reviving the classic character of rural community batik, that describes about diversity in the Javanese community.
\end{abstract}

Keywords: Batik Girilayu, classical, design, contemporary, reproduction

\section{INTRODUCTION}

Character is a concept which has become the soul in a batik motif design. This becomes an important part in determining the philosophical, aesthetic, and economic values of batik motif design works. When functional factors and visual aesthetics are merely poured into a work without strong concept, the design of batik motifs will simply be a kitsch or artistic rubbish. Design's character can be specifically seen in physical forms, such as in the form of curve lines, colors, patterns, contours, textures, volume, material used, and how it is presented [1]. The role and influence of the designer determine the value of the work totality. The influence can be seen from the details of the work which is made repeatedly and continuously, so that there is recognition from the public community about the characteristics of the work, including on batik design.

The introduction of batik designs from the predecessor generation to their younger generation as well as children in the Javanese community, is done verbally and through the use function when any traditional ceremony takes place [2]. Documenting stories and 
descriptions of objects in writing is rarely done in the customs of Javanese people, except in the administrative scope of the ancient kingdom as reflected in the form of regulations, laws, notifications, and procedures [3]. Storytelling or telling stories is a way to convey lessons, advice, and how to effectively communicate without patronizing. Tales or stories are told by mothers to their children during making batik process, while wearing batik cloth on special events such as the seven-month pregnancy (mitoni), marriage, and death ceremonies. There is an interesting story about a piece of batik cloth in Javanese community. Most Javanese people still believe in the healing power of a piece of batik cloth which is wrapped around a child's body whose fever. The batik cloth is usually inherited from generation to generation to the closest familt or relatives who are willing to care for and look after the cloth. The origin of this batik cloth functioning as the healing property may vary; some are previously used for covering their family dead body, some are worn by the mother during childbirth (jarik kopohan), and the others are handmade from their grandmother or mother as a wedding gift. The best batik cloth only appears or is used at two important events in the life cycle, marriage and death. At the wedding ceremony, the parents of the bride wear uniform batik cloth (sarimbit) withTruntum motif. Parents whose expertise or work as batik artists will make their own hand writing batik to be used when they wed their children (mantu). The number of this batik is 2 pairs of motifs, i.e. 1 pair of Truntum motif worn by parents, and 1 pair of Wahyu Tumurun motif worn by the bride and the groom. In addition, at the death ceremony, the batik motif used is from diverse backgrounds, such as it has been prepared by the dead person when he/she was still alive (made by him/herself or ordered at the best handmade batik artists), a hereditary batik cloth specifically used by large families for lurub layon or as corpse cover. If there is no special batik cloth prepared, the family will select the best quality batik cloth with the dead's favorite batik motif. Furthermore, if the dead doesn't have any favorite batik motif, the family will use the best batik cloth they own. Category of the best fabric is shown from its motif, color, the quality of mori unbleached plain cloth or cotton used to make batik cloth [4].

Daily activities which used to be a means of communication to convey the meaning behind batik cloth between mothers and daughters (especially) when the daughters are being combed, when the mother is showing or helping their daugther how to wash and fold batik cloth, and when the mothers help put the batik cloth on the daughters for special events. The loss of this habit of communicating the meaning of batik cloth through fairy tale or story indirectly becomes a problem for the sustainability of tradition batik. Batik motifs whose meanings are rarely passed down from generation to generation are likely to be lost and will be difficult to be reproduced as there are no written or oral sources about the motif. One of some efforts which can be taken and strived to preserve batik motifs is through reproduction by combining the character of classical batik in modern or contemporary designs [5]. This design reproduction step has been taken by batik artists in Girilayu, Matesih subdistrict, Karanganyar Regency, Central Java. The purpose of batik artists to make contemporary motifs with classical characters is to preserve the noble (adi luhung) of tradition batik culture or nguri-uri kabudayan luhur (preserving noble culture) of which its existence is currently threatened due to technological advances [6]. Change and progress are a necessity in culture; however, defending, preserving, and continuing the tradition is an obligation for future generations. Tradition is the identity of a community and even a large nation like Indonesia. The diversity of traditions is an indicator of cultural assets wealth as the basis for a country's development [7]. Moreover, the nobleness of batik tradition lies in the transcendental meaning or spirituality in the process of making batik, the meaning and the function of batik cloth. Some previous research has discussed the topic of tradition continuity especially in batik, but there was not discussed how to reproduce classical character in the batik design [8]. This study aims 
to describe the motivation in the reproduction activities of Surakarta style classical characters in batik, to find out the creative process of batik in developing batik designs with classic characters, and to reveal the meaning of contemporary batik design motifs which reflect Girilayu's values and social norms. This study on the reproduction of classical character in the contemporary design of Girilayu batik is expected to gain a beneficial result for the continuation of the tradition in a specific way.

\section{METHOD}

This study used qualitative method focusing on the activities of Girilayu batik artists' community to reproduce Surakarta-style classical batik motifs. In addition, hermeunitic approach is used to describe the meaning of the concepts and creative processes, thus it can form a description of a social characters series in batik works with contemporary design resulted from reproduction activity [9]. Data collection was conducted in two ways, i.e. interviews and literature studies. Interviews were done with batik artists' groups who also worked as designers in Girilayu. Moreover, the topic of the interview was about the reproduction efforts of batik in contemporary design related to the concept, process, and background. Furthermore, the interviews were conducted randomly with batik artists and community leaders who know about the reproduction activities of classical batik in Girilayu. The selection of the informants was based on the recommendations from village administrative stakeholders. The interviews were conducted aiming to collect and obtain actual data presentation from Girilayu batik artists' group about the effort of reproducing contemporary motifs and designs. Literature study was carried out by collecting documentation, literature, and archives related to classical character batik style, Girilayu batik, batik contemporary design, and Girilayu batik community. The results of previous studies on the development of classical style batik designs were used as a research guide, especially for the statement of position and the novelty elements existing in the study. Hence, the data obtained through literature studies were used to crosscheck (validity), to strengthen the data, and to scientifically guide the analysis [10].

\section{RESULT AND DISCUSSION}

Public awareness from across circles for the effort of batik tradition sustainability has reached the implementation level. This is a good step for the ecosystem of tradition batik in Indonesia. Indonesian batik in 2019 has exactly 10 years received recognition from UNESCO as an intangible world heritage. This recognition requires a long process and struggle from the bureaucratic, cultural, and strong historical documentation aspects [11]. The recognition as an intangible world heritage on Indonesian batik is not for the beauty of its diverse ornaments or ornamental motifs. Instead, it is on the process mainly on the use of canting (special tool to dra batik on fabric using wax) as well as on the deep implicitly philosophical meaning in each piece of batik cloth. Evaluation is continuously carried out by UNESCO on Indonesia's eligibility to keep receiving such recognition; thus the effort to maintain the continuity of tradition batik by various groups in Indonesia nowadays is the right protective act as chances of stagnation or referenced transfer resources can occur [12].

Stagnation or the cessation of the tradition batik continuation activities can occur due to the decreasing protective efforts done by the authorities in the form of binding regulations; for instance, technological advance in the form of machine to make tradition batik by using the principle of batik process with canting and wax. If the regulations regarding the restriction on 
the volume of production are not issued, it will obviously shift the local wisdom, in the form of the ability to manually draw batik using hand and canting [13]. The context of the problem arises due to the absence of official regulations clearly governing the corridors of industrial commercial interests with the continuation of tradition batik. Currently, profit from industrial scale utilizing the expertise and potential of local community cannot be obtained by them as the main actors. The position of batik artists with local wisdom who is able to produce noble (adi luhung) batik is now at the bottom of industrial hierarchy. They, the batik artists, are not placed fairly like the maestro and assets of the nation, but they are only considered as the workers or sanggan (term for batik artists [workers] who use canting) whom are paid for every piece of cloth. Sanggan in Javanese is derived from the word sangga (adjective) or nyangga (verb) which means 'to sustain'. In fact, those sanggan are the main pillars of handdraw tradition batik industry which still rely on the talents and expertise of women who use their hands to manually make batik [14].

Girilayu, Matesih subdistrict, Karanganyar regency, Central Java province of Indonesia, is one of the regions whose communities which still maintain the continuity of tradition batik. Girilayu is located $32.2 \mathrm{~km}$ eastern of Surakarta or Solo Municipality (same level as regency). It is geographically situated at an altitude of $660 \mathrm{~m}$ above sea level on the slopes of Mount Lawu. Batik communities in Girilayu realize that their position is in the lowest hierarchy in the batik industry. Nevertheless, batik artists in Girilayu since a long time ago have been taught by their predecessors or ancestors to appreciate batik as a product of tradition with a wholehearted process as caring for and raising their own children. Expressions or saying of prayer reflected into motifs whose rich meaning on a piece of cloth are literal meanings resulted from the abstraction of local wisdom, values, norms, and rules existing in the community. Industrial exploitation, technological sophistication, and regulations issued by policy makers who do not support batik artists become the background of their efforts to reproduce classical motifs which are almost lost due to the lack of sustainability processes, especially the habit of storytelling and telling the meaning of batik cloth in the scope of family. The reproduction is carried out for several purposes, i.e. creating new motif designs as a characteristic of batik products, as a new medium to restart the habit of telling stories about the meaning of batik cloth, and adding variety to contemporary batik designs with classic characters in Girilayu. Moreover, there was an agreement made among batik makers in Girilayu stating that the designs of contemporary motifs with classical characteristics were not made for industrial purposes and were not sold elsewhere. This step indirectly protects contemporary motifs from being mass produced by using printing or digital machine which will considerably eliminate the sublime meaning of its tradition process as well as its local wisdom elements [15].

Classic character of batik style chosen by Girilayu batik artists in developing contemporary batik designs was based on historical ties between Girilayu and Surakarta, essentially Puro Mangkunegaran kingdom. The Giyanti Treaty year 1755 and the Salatiga Treaty year 1757 were agreed to end the conflict in Mataram Kingdom. One of the results decided in the agreement was territorial division which mentioned Girilayu as a praja (as sub-district level now) under the authority of Mangkunegaran kingdom. Although Mangkunegaran was independent in a form of power, but for the physical visual character of some objects, it still uses the style or gagrag of Surakarta, officially named Surakarta Hadingingrat Palace, as the center of power which supervises Mangkunegaran. The character of Surakarta-style classical batik generally lies in the composition of coloring and isen - isen (content: ornament, lines, etc) motifs. Coloring on the character of classical batik Surakarta style is dominantly golden brown which is obtained from Soga plant. This plant thrived in the land of Java in ancient 
times. The characteristic color of Soga tree became the term to refer to the tone of Surakartastyle classical batik as Sogan or adjective for the natural brown batik color from Soga wood extraction. The ease in obtaining natural brown coloring agents around Surakarta caused batik cloth to be dominated by brown colors ranging from light to dark tone depending on the mixture used. Soga wood extraction mixed with Tingi wood will produce reddish brown color. While Nila tree or Indigo mixture in Soga wood extract will produce a dark bluish brown color. There is a clear difference in the classical character for Surakarta batik in Mangkunegaran region as the brown color used is derived from the original Soga color by manipulating the color using some dose composition; hence it may create light brown to dark brown without red color of Tingi wood or blue dye elements from Nila plant. The next character which emerges from Surakarta-style classical batik is the details of isen - isen used. Isen-isen or small ornamental motifs in the form of shapes configuration as the results of dots and lines composition are used to enrich the details on motif appearances. Isen - isen or content on Surakarta-style classical batik philosophically means fulfilling, completing, or enriching overall motif [16].

Sogan colors and isen - isen details as the main characters of Surakarta-style classical batik are by batik artists in Girilayu reproduced in contemporary batik designs. The repetition done by entering Surakarta's classic batik style with motifs development inspired by Girilayu's potential, such as Tugu Tri Dharma (Tri Dharma Monument) and their superior crops as mangosteen durian. As a result of this development, Girilayu community succeeded in grouping batik artists under the name Tugu Tri Dharma, as well as grouping batik motifs like Semen (motif with description of growing life), Parang (motif with description of slope, vertical lines), Lereng (motif describing dynamic and flexible personality, simpler than parang motif), Sido (describing continuity, the ornament is like beautiful butterfly), and Ceplok (geometrical motifs like circle, square, star shape; describing life destiny). Tugu Tri Dharma motif group was stated as the result of reproduction of Surakarta batik classic character in Girilayu's batik contemporary design. The basis of the grouping is carried out by batik artists' community to revive the learning about Tri Dharma (three guidances) view of life from KGPAA Mangkunegara I. The noble teachings contain an invitation to the community to have a sense of responsibility for maintaining the continuity of all tradition and cultural forms, possessing the courage to defend and protecting themselves if there is anyone or anything trying to damage the social order, and conducting self-introspection or prioritizing ingenuity common sense in solving problems. There was found a Javanese educational value in the concept of Tri Dharma. It was taught a clear implementation in one of the motifs named Tugu Tri Dharma as a basic motif. The visualization process of classical style batik in the Tugu Tri Dharma motif was based on the Nyawiji principle. Nyawiji means fusing all elements into a new motif unity, and its strong message of a Javanese people about diversity that describes from the reproduction of classical character in the contemporary design of Batik Girilayu.

\section{CONCLUSION}

The effort taken by Girilayu batik artists' community to reproduce classical characters of Surakarta-style batik is an interesting breakthrough, though it is not new either. The enthusiasm of batik artists' community to maintain the continuity of tradition batik through learning the meaning of motifs in Tugu Tri Dharma contemporary design to the next generation is the first step towards the continuation of tradition and spiritual values as a way of life. Protection on these motifs is done by community agreement, i.e. not to make 
contemporary Girilayu batik designs to be commercialized through large batik traders (wholesaler) in Surakarta (Solo), as what they have been doing for a long time. They realize this agreement has a weakness of which it may be violated. Hence, the discourse to start processing motifs copyright motives began to accomplish. The existence of technological advances and industrial innovations to quickly produce batik with large capacity becomes a dilemma. In one side, technological progress is necessary to adjust the changes which demand fast-paced, good, and hi quality products; on the other hand, tradition must literally be preserved in its original format. However, what is happening currently is that the values of conventional traditions are trying to be summarized and simplified as well as be made easier for the reason to adjust with the times and to increase its economical values or profit; consequently, some of the tradition authenticity is lost. The word originality in tradition in Indonesia, especially batik is now difficult to formulate. Tradition Batik in Indonesia has eventually experienced a reduction in the process and history due to the lack of community habits to document them in a detailed written script or description. The government needs to issue a policy to legally strengthen and bind the efforts done by the community in maintaining tradition; one of the efforts is reproduction of classic batik in contemporary designs.

\section{REFERENCES}

[1]. D. Nurcahyanti and T. B. Affanti. "Pengembangan Desain Batik Kontemporer Berbasis Potensi Daerah dan Kearifan Lokal”. Jurnal Sosioteknologi, Vol. 17, No. 3, pp. 391-402, 2018.

[2]. E. Purnamasari, E. W. Nugroho, and A. D. Widian. "The Introduction of Classic Batik Motif to the Community Through Game". Sisforma, Vo; 4, No.1, pp. 31-36, 2017.

[3]. T. Suliyati and D. Yuliati. "Pengembangan Motif Batik Semarang untuk Penguatan Identitas Budaya Semarang”. Jurnal Sejarah Citra Lekha, Vol. 1, No. 1, pp. 61-73, 2019.

[4]. J. Selamet. "Indonesian Batik Translation: A Case Study". International Journal of Visual Design, Vol. 12, No. 3, pp. 11-17, 2018.

[5]. A. Wahida, E. S. Handayani, and F. R. Fuad. "Aesthetic Values of Classical Batik as the Sources of Contemporary Painting Ideas". Advances in Economics, Business and Management Research (AEBMR), Vol. 41, pp. 121-125, 2017.

[6]. E. Sediyono, T. Mahatma, and I. A. Hunga. "Knowledge Management of Traditional batik in Central Java". International Journal of Engineering \& Technology, Vol. 7, No. 4, pp. 143-146, 2018.

[7]. H. T. Meisyaroh, H. Pratikto, and P. Handayani. "Maintaining Local Wisdom of Batik Culture to Improve Competitiveness in International Business: Case Study on Batik Jokotole Collection in Bangkalan Cityu, East Java, Indonesia”. The International Journal of Business \& Management, Vol. 7, No. 4, pp. 216-221, 2019.

[8]. M. D. Kusumawati and E. R. Hartowiyono. "Philosophy, Design Batik Yogyakarta, and Batik Surakarta Made in Indonesia." International Journal of Latest Trends in Engineering and Technology, Vol. 8, No. 3, pp. 91-99, 2017.

[9]. M. R. Kholid. "Canting as A Symbol of Culture and Economics Development in Novel By Arswendoatmowiloto (A Study of hermeneutics)". Jurnal Tadris Bahasa Inggris, Vol. 9, No. 1, pp. 103-128, 2016.

[10]. M. Staudigl \& G. Berguno. Shutzian Phenomenology and Hermeunitic Traditions. Dordecht, Heidelberg, New York, London: Springer, 2016.

[11]. L. M. Hakim. "Batik sebagai Warisan Budaya Bangsa dan Nation Brand Indonesia". Nation State: Journal of International Studies, Vol. 1, No. 1, pp. 60-89, 2018.

[12]. R. Syamwil. "Conservation of Batik: Conseptual Framework of Design and Process Development". AIP Conference Proceedings 1941 of Engineering International Conference (EIC 2017), pp. 1-10, 2018. 
[13]. S. T. F. Poon. "The Journey to Revival: Thriving Revolutionary Batik Design and Its Potensial in Contemporary Lifestyle and Fashion”. International Journal of History and Cultural Studies (IJHCS), Vol. 3, No. 1, pp. 48-59, 2017.

[14]. I. E. Suryani, L. Anggraini, \& U. Suryadi. "Strategy Formulation for Developing Batik Tulis, Indonesian Journal of Business \& Entreprenurship". Indonesian Journal of Business \& Entrepreneurship, Vol. 1, No. 1, pp. 23-31, 2015.

[15]. R. Dinata and Z. Fan. "Elaboration of Batik Pattern Design Science Application in Indonesia". International Humanities and Applied Science Journal, Vol. 2, No. 2, pp. 50-57, 2019.

[16]. K. Saddhono, S. T, Widodo, M. T. Al Makmun, and M. Tozu, "The study of philosophical meaning of batik and kimono motifs to foster collaborative creative industry." Asian Soc. Sci. vol. 10 no. 9 pp 52-61, 2014 